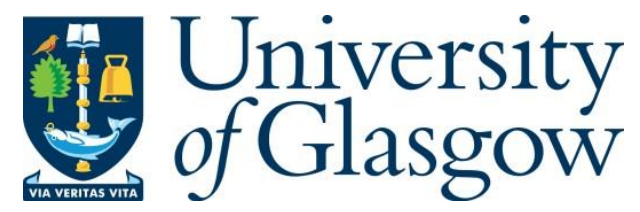

Cumbers, A. and Paul, F. (2020) Adapting to the political moment and diverse terrain of 'actually existing municipalisms'. Soundings: A Journal of Politics and Culture, 74, pp. 40-53.

There may be differences between this version and the published version. You are advised to consult the publisher's version if you wish to cite from it.

http://eprints.gla.ac.uk/229022/

Deposited on: 20 January 2021

Enlighten - Research publications by members of the University of Glasgow

http://eprints.gla.ac.uk 


\title{
ADAPTING TO THE POLITICAL MOMENT AND DIVERSE TERRAIN OF 'ACTUALLY EXISTING MUNICIPALISMS'1
}

\author{
Andrew Cumbers and Franziska Paul \\ Adam Smith Business School \\ University of Glasgow
}

Published in Soundings (2020)

Tried and trusted forms of municipalism will continue to play an important role in any new municipal alliances.

The Labour Party's defeat in the 2019 UK general election was a critical blow not just locally but to the broader international left. The hope that inspired the Corbynite project, and the detailed (and broadly popular) alternative policy proposals for a more democratic political economy, including considerable levels of state and cooperative ownership, were brutally extinguished in the harsh and unforgiving glare of electoral politics.

For Labour, the loss of seats in some of its old industrial heartlands to the Conservatives, and the apparent appeal in these constituencies of Boris Johnson's pro-Brexit right-wing populist narrative of 'taking back control', was of seismic significance. But the growing alienation of some of the most deprived places and sections of the working class from the social-democratic establishment goes back a long way, and is a Europe-wide phenomenon. In the UK, this can be traced to the 'taken for granted' top-down managerialism of New Labour, and even to the 'managed decline' of coalfield areas by the more socially democratic-minded Labour governments of the 1960s and 1970s. ${ }^{2}$

Faced with the growing threat of right-wing populism and a potentially more conservative localism in its former political heartlands, the task for Labour is to reengage with such detached communities in a democratic and politically meaningful way. The scale of the election defeat means it will likely be out of power for five and possibly ten years at the national level. This provides an urgent imperative in the first instance to develop more progressive local policies - not just as a way back for a left

\footnotetext{
${ }^{1}$ This paper partly draws upon research funded by the European Research Council: 'Global Remunicipalisation and the Post-Neoliberal Turn'. See here for further details.

${ }^{2}$ Huw Beynon, Ray Hudson and David Sadler, A Tale of Two Industries, Open University Press, 1991.
} 
politics in the UK - but also in recognition that local politics is always integrally linked to the national. ${ }^{3}$

The dilemmas facing Labour are shared by the left in many other countries. More moderate, centre-left 'Third Way' triangulation projects of neoliberal globalisation are in terminal decline. Meanwhile left alternatives seem unable to gain traction at the national scale, with the important exception in Europe of Portugal (and more recent developments in Spain after a long struggle to form a left-wing coalition). This means that calls in the UK for Labour to build a new grassroots radical democratic localism chime with the wider left international interest in the possibilities of a 'new municipalism', where the local scale is seen as a productive terrain for revitalising an international left politics of solidarity and social justice. ${ }^{4}$

In this article we engage constructively with the 'new municipalism', but we also caution of the dangers of imposing another set of top-down elite imperatives on 'left behind places'. Instead, while drawing upon positive experiences from the recent global remunicipalisation trend, we want to also highlight the importance of working with 'actually existing' municipalisms on the ground. Productive coalitions and new alliances for a renewed left municipalism can be built through working with the continuing and diverse forms of municipal values and cultures that are already in existence.

\section{The hope of a new municipalism}

In May 2015, Spain experienced something of a political earthquake at the local level when 'citizen's platforms' won municipal elections in four of the country's leading cities (Barcelona, Madrid, Valencia and Zaragoza), as well as a host of smaller ones. These insurgencies were linked to a broader national rejection of mainstream political parties and the rise of Podemos as a radical left alternative, evoking the spirit of a more participatory and grassroots democracy against a national climate of neoliberal austerity. Barcelona - where the social movement Barcelona en Comú (BEC), which translates literally as 'Barcelona in Common', won the election with one of its leaders, housing activist Ada Colau becoming the city's mayor - was the most celebrated success story.

Two years on, in June 2017, Barcelona hosted the first Fearless Cities Summit. This was the coming together of a self-proclaimed 'global municipalist movement' of 700 attendees from around the world, including cities as diverse as Beirut (Lebanon), Jackson (Mississippi), Zagreb (Croatia) and Rosario (Argentina), dedicated to 'defend human rights, democracy and the common good' whilst also having the goal 'of

\footnotetext{
${ }^{3}$ As supporters of a radical democratic independent and outward-looking Scottish state within the European Union, we are mindful of the very different political trajectories that exist across the UK's nations and regions. There is not the space here to allow for a fuller critical reflection on these issues but the general tenor of our comments on municipalism apply more universally.

${ }^{4}$ On radical localism see Phil Jones, 'Look to Preston for an answer to Labour's - and Britain's - woes', The Guardian, 13 January 2020.
} 
radicalizing democracy, feminizing politics and standing up to the far right' (see Fearless Cities website: http://fearlesscities.com/en/about-fearless-cities).

What is also interesting for us here is the departure this represents from much existing autonomous-inflected and anarchist practice (which has been a key influence in the new global municipalism movement). This has tended traditionally to decry any involvement with the local state and political institutions. What distinguishes the new municipalist discourse, articulated by the Fearless Cities Summit, is the aim of a more productive yet critical engagement with the public spaces of the municipal state. Though it is committed to decentralisation and local autonomy from centralised government, the new municipalism also seeks to open up municipal state spaces to more radical and democratic practices of selfgovernment. Laura Roth, one of the founding figures of Fearless Cities, quoting Debbie Bookchin's comment that 'municipalism is not about implementing progressive policies, but about returning power to ordinary people', continues:

In fact, municipalism emerges in many places precisely as a response to the lack of democracy of public institutions and traditional political parties. For example, many municipalist candidacies utilise open and participatory processes to develop their political programmes 'from below', drawing on the collective intelligence of the population. ${ }^{5}$

These initiatives are avowedly anti-parochial, and offer some hope for a broader revival of the left. Critical to their vision is the sense that the municipal scale is seen as a 'strategic front' championing a broader set of democratic values, shared translocally across social movements and actors such as those making up Fearless Cities. ${ }^{6}$

\section{Whose municipalism?}

This evocation of a more progressive localism is surely an important counter to the threat of increased support for a more right-wing and conservative localism. ${ }^{7}$ But the imminent dangers of the latter, and its full implications, need to be critically engaged with, and confronted by, the new municipalism. Returning for a moment to the UK, a recent and perhaps underestimated phenomenon, that in some ways foreshadowed Labour's election defeat, has been the election of two right-wing local mayors for the newly created combined metropolitan authorities of the West Midlands and Tees Valley in the party's former industrial heartlands. It is important that municipal activists engage with the complexities that produce such results.

In Tees Valley, Conservative mayor Ben Houchen recently 'nationalised' a failing local airport, something that would have seemed anathema to the party of Thatcherism

\footnotetext{
${ }^{5}$ Laura Roth: https://www.opendemocracy.net/en/can-europe-make-it/whichmunicipalism-lets-be-choosy/.

${ }^{6}$ Bertie Russell, 'Beyond the Local Trap: New Municipalism and the Rise of the Fearless Cities', Antipode, 2019.

${ }^{7}$ David Featherstone, 'Progressive localism and the construction of political alternatives', Transactions of the Institute of Geographers, 2012.
} 
only a few years back. Houchen has pledged $£ 40$ million of scarce public resources, in a region pulverised by Conservative austerity and local government cuts of over 20 per cent per annum since 2010, on what has been described as a 'vanity project' for a small local airport that makes $£ 2$ million losses per year. ${ }^{8}$ But the move was very popular locally, and seemed to capture a frustrated sense of a left-behind place in a region whose main city, Middlesbrough, has the highest number of deprived neighbourhoods in England. ${ }^{9}$ The municipal takeover involved the rebranding of the airport from Durham Tees Valley to Teesside International, after a popular vote by 14,000 people. This move, labelled as providing more visibility for international investors, captures the hollow promises of a post-Brexit landscape in a region that has endured four decades of failed regeneration efforts following the dramatic collapse of its steel, chemicals and engineering industries in the late 1970s.

Whatever the errant nonsense of these latest claims, there are clearly dangers here for alternative left municipalist visions in responding to those of the right, if they fail to engage and embed themselves in evolving attitudes and everyday lived experiences in particular places. Too often, left narratives of municipalism evoke the usual radical suspects, such as Berlin and Barcelona, whilst perhaps missing the potential of more mundane localisms in less celebrated places.

Even the depiction of a set of 'Fearless Cities' does potentially set up a binary with other more 'fearful' places. Conservative localist projects, such as those at work in Tees Valley, seem adept at seeing to be doing something, 'sticking up for' the left behind against 'metropolitan liberal elite' condescension. At the same time, they are adept at manipulating a fast-changing media landscape, skating over more deepseated political and economic inequalities, and moving on before the dust fully settles to the next electoral narrative.

This is a highly effective local politics - something that the left, with its often worthy but rather more abstract focus on broader universalist visions - often misses. As John Tomaney has put it in his thoughtful defence of local political and cultural identities: 'The attempt to situate the local in wider processes contains its own dangers, mainly failing to account for the persistence of local attachments and neglecting their potential value. ${ }^{10}$ In aspiring to return power to 'ordinary people', a left internationalist municipalism must guard against the disdain and condescension of the 'world beyond belonging' of the 'cosmopolites'. ${ }^{11}$

${ }^{8}$ Chris Tighe, 'Why a Conservative mayor is trying to take over local airport', Financial Times, 2019: https://www.ft.com/content/62cd391c-0459-11e9-9d01cd4d49afbbe3.

${ }^{9} \mathrm{MHCL}$, The English Indices of Deprivation, 2019,

10 John Tomaney, 'Parochialism: a defence', Progress in Human Geography, 375 2012, p664.

${ }^{11} \mathrm{lbid}$, p. 669 
For us, influenced very much by the late founding editors of Soundings, Stuart Hall and Doreen Massey, a more effective engagement with local politics requires a more critical consideration of, particular political moments in time and space; thinking openly and adaptively about their threats and possibilities for left political strategy. This is particularly the case at a moment of significant - conjunctural change. As Hall memorably put it in his analysis of the left's failures to confront the earlier populism of Thatcherism:

When a conjuncture unrolls there is no 'going back'. History shifts gears. The terrain changes. You are in a new moment. You have to attend 'violently' ... to the discipline of the conjuncture. ${ }^{12}$

Massey also urges us to think spatially about the politics of conjunctures; both in terms of the wider spatial politics within which places are situated, but also in being attentive to diverse place-based configurations. ${ }^{13}$ Thinking of the new municipalism in conjunctural terms requires us to be attentive to the diverse character and potential of municipalism, fusing broader trans-local movements for social and ecological justice with actually existing 'on the ground' experiences.

\section{Global remunicipalisation as a set of 'actually existing municipalisms'}

It is with this in mind that we depart here from the lofty aspirations, but still fragile foundations, of the new municipalism, to focus on a less celebrated and more mundane phenomenon, the recent global trend referred to as remunicipalisation which we would frame for the purposes of this discussion as an 'actually existing' set of municipalisms. These forms of municipalism will play an important role in the development of any future forms of local politics.

The process of remunicipalisation has been evident since the early 2000 s, whereby towns, cities and in some cases sub-national regions have taken previously privatised and increasingly financialised assets, services and infrastructure back into forms of local public - hence municipal - ownership. ${ }^{14}$ The most common motivation behind remunicipalisation has been as a response to the poor experiences of service provision under privatisation. This is, for example, the case in the water sector where rising costs and prices to consumers after privatisation have been associated with poor performance and lack of delivery of promised modernisation and infrastructure spending, a situation mirrored elsewhere. While the problems with privatisation in the water sector are fairly well documented, increasingly - and importantly - the

\footnotetext{
12 Stuart Hall, The Hard Road to Renewal: Thatcherism and the Crisis of the Left, Verso 1988, p162.

${ }^{13}$ See also the recent work in geography on the spatial dimensions of a conjunctural analysis with theoretical, political and methodological implications (e.g. Featherstone, D. and Karaliotas, L. Challenging the spatial politics of the European crisis: nationed narratives and trans-local solidarities in the post-crisis conjuncture. Cultural Studies, 322 2018, pp. 286-307.

${ }^{14}$ On financialisation of assets see Andrew Pike et al, Financialising City Statecraft and Infrastructure, Edward Elgar 2019.
} 
trend towards remunicipalisation can also be found in other sectors covering almost all areas of local public and social service provision.

This is a global process - taking place on all continents but with a geographically uneven spread, with strong concentrations evident in Germany, the United States and France. Some of the earliest and most celebrated examples occurred in Latin America and were part of wider uprisings against the consequences of Washington Consensus-inspired policies of privatisation and marketisation, but significant remunicipalisations have also occurred in countries as diverse as Tanzania, Malaysia, India and Lithuania. In 2017, the Transnational Institute (TNI), an Amsterdam-based think tank, documented 835 cases worldwide of cities, towns and regions that have taken privatised public services back into forms of local public ownership. ${ }^{15}$ The trend is evident across a range of sectors, including water, energy, waste, local government, transport, education, and health and social services. Subsequent research by TNI has revealed over 1400 cases in an updated study, presented the recent 'The Future is Public' conference held in Amsterdam. ${ }^{16}$

Remunicipalisation struggles are infused with contentious and open politics; they often involve mass campaigns of civic action and engagement, and have taken place in cities as diverse as Hamburg and Cochabamba. These are struggles over vital public assets, resources and infrastructures, critical to the functioning of towns and cities, but also vital to the health, wellbeing and livelihoods of citizens. They are the battles over the mundane but crucial local resources of everyday life, capable of uniting activist cadres with broader coalitions at the municipal level. Equally important have been successful struggles to resist privatisation, particularly in the water sector, where citizens have been mobilised to retain public ownership. ${ }^{17}$

It is important to recognise that the political effects of remunicipalisation do not always lead to progressive outcomes. In his analysis of the water sector David McDonald recognises diverse currents at work, ranging from an autocratic state capitalism in Orban's Hungary, to 'market managerialism', social-democrat forms and, in a minority of cases, a more democratic socialist impulse. ${ }^{18}$ At the same time, many remunicipalisations turn back to the same top-down management, and localelite politicians and government technocrats, that were responsible for privatisation in the first place. The articulation of each process of remunicipalisation is thus heavily dependent on the particular context in which it takes place. As privatisation collapses as a form of local governance, different political trajectories are likely. But

\footnotetext{
${ }^{15}$ Satoko Kishimoto and Olivier Petitjean (eds), Reclaiming Public Services: How cities and citizens are turning back privatisation, TNI et al, 2017.

${ }^{16}$ Satoko Kishimoto, Lavinia Steinfort and Olivier Petitjean (eds), Draft report prepared for The Future is Public conference. The Future is Public: Towards democratic ownership of public services, TNI, 2019

${ }^{17}$ Hilary Wainwright, The Tragedy of the Private, the Potential of the Public, PSI \& TNI, 2014.

${ }^{18}$ David McDonald, 'Remunicipalisation: The future of water services?' Geoforum 91, 2018.
} 
whatever these trajectories may be, it is clear that remunicipalisation processes offer spaces where different and more citizen-engaged forms of democratic public organisation can be articulated and fought for - including the struggle for a different kind of local state, public ethos and values. Such campaigns can also lead to new progressive coalitions that can transcend established political identities.

Germany, where remunicipalisation in the energy sector has been both prominent and well-documented, offers important insights in this respect. While sometimes tied to a decidedly radical left agenda, for example in the case of Hamburg's successful social movement campaign and resulting public referendum on the remunicipalisation of energy grids for electricity, gas, and district heating, not all examples of remunicipalisation in Germany are actively politicised. ${ }^{19}$

Remunicipalisation projects typically receive more support from left and socialdemocratic parties, including DIE LINKE (the Left Party) and the Social Democrats (SPD), and are approached with a degree of scepticism from traditional conservative and market liberal parties, such as the Christian Democrats (CDU) and Free Democrats (FDP), but there are also many cases where local politicians from all parties come together. For example, the Free State of Bavaria, a majority conservative state since 1945 (except in its capital Munich which is governed by the SPD), has the highest number of publicly-owned enterprises anywhere in Germany. Remunicipalisation, much like other processes taking place on the municipal government level, is often a cross-partisan issue in Germany. (As we discuss in more depth in the next section, it is important to understand the wider context for this phenomenon - which is that there remains a particular and strong public ethos in Germany. Reflecting on this ethos yields important insights into the wider establishment of pro-public politics, as well as pointing to opportunities to more actively establish a progressive politics around these processes.)

Our point here, however, is that the ongoing failures of privatisation, as well as the campaigns for remunicipalisation, present a productive terrain for forging different and more democratic forms of public institution; but these should be attentive to local and historical context, such that a new municipalism can build alliances with existing and older forms of municipalism. If the left is to start to take advantage of neoliberalism's contradictions, becoming more adept than the right at capitalising on its tendency to 'fall forward', ${ }^{20}$ it needs to broaden its coalition of municipal action.

\section{'Öffentliche Daseinsvorsorge': municipalism as a mandate of public trust}

In this sense, while new initiatives are emerging at the local level in cities such as Barcelona and Grenoble, which are often described as cases of a 'new municipalism' as they clearly push back against neoliberal governance, there is also a point to be made about the contexts in which longstanding values of 'public ownership' and

\footnotetext{
${ }^{19}$ Sören Becker, 'Our City, Our Grid: The energy remunicipalisation trend in Germany', in Satoko Kishimoto and Olivier Petitjean (eds), Reclaiming Public Services, TNI 2017.

${ }^{20}$ On 'falling forward', see Jamie Peck and Nik Theodore, 'Still neoliberalism?', South Atlantic Quarterly, 2019.
} 
'public provision' continue to flourish, or have never fully disappeared. As Stuart Hall has noted, neoliberal values are never totally dominant or complete. Hegemony always needs to be worked at: it is also resisted, and has to co-exist alongside other social identities and values. Even in the neoliberal heartland of the UK, public ownership has been stubbornly popular: there have been substantial majorities in favour since the $1980 \mathrm{~s} ;{ }^{21}$ and one little remarked phenomenon to which we would also draw attention is the trend since 2000 for UK local authorities to take formerly out-sourced services back in house to save on costs - ironically, many are spurred on by the experience of austerity-driven national policies. ${ }^{22}$

Germany has become the epicentre of remunicipalisation, particularly of electricity infrastructures and provision, where there have been 305 cases of remunicipalisation in the energy sector. ${ }^{23}$ This has been driven partly by the strength of the environmental movement and the country's Energiewende (energy transition), but it also reflects a deeper historical ethos of public value, evident in both urban and rural regions in Germany as well as its neighbours Austria and Switzerland. The German term and concept of öffentliche Daseinsvorsorge is interesting here, as it translates, effectively, to 'public (well-)being provision'. ${ }^{24}$ As such, it is already indicative of a particular public ethos that has continued to exist in Germany as well as its German-speaking neighbours and in parts of Scandinavia. The German understanding of public service, as a responsibility to care for the well-being of those living within a municipality, is deeply rooted within wider German public management discourses, and, importantly, remains anchored in the administrative structures of German federal states. Historically, the term öffentliche Daseinsvorsorge dates back to the mid-nineteenth century, from when it expanded in both popularity and sectors to eventually be at its most comprehensive in the German and Scandinavian social-democratic welfare states post-World War II. ${ }^{25}$

Even at the height of neoliberal policy-making in the 1980s, Germany never fully embraced the far-reaching and more comprehensive privatisations experienced in the UK. While key utilities were also privatised in Germany, certain 'backstops' were kept in place, which ensured a measure of continuing local municipal control, for example in the form of concessions rather than wholesale sell-offs. On a basic level, these allowed the renegotiation of contracts after a pre-defined, twenty- to thirtyyear time period following privatisation. This legal framework allowed many German local authorities to re-purchase, or remunicipalise public services and infrastructures from the mid-2000s onwards, a trend that intensified in scale and scope after the

${ }^{21}$ A. Cumbers, Reclaiming Public Ownership: Making Space for Economic Democracy, Zed 2012.

22 David Hall, Remunicipalising Public Services in Europe, PSIRU 2012.

${ }^{23}$ Draft report for The Future is Public conference.

${ }^{24}$ Hellmut Wollmann and Gerard Marcou (eds), The Provision of Public Services in Europe: Between State, Local Government and Market, Edward Elgar 2010.

$25 \mathrm{lbid}$. 
financial crisis of $2008 .{ }^{26}$ Another interesting feature here is the continuing decentralisation and municipal control of local utility provision, unlike in the UK state, where political agency was heavily centralised through nationalisation and subsequent privatisation, with local agency all but extinguished in key utilities, from rail to water to energy.

Transparency and trust: The case of Darmstadt's 'Stadtwirtschaftsstategie' An 'actually-existing' municipal example, which illuminates further this continuing public ethos in Germany, is the case of Darmstadt, the regional seat of one of the three administrative provinces (counties) of the state of Hesse. Due to its prominent role up to the first half of the twentieth century, when it was the capital of the former Grand Duchy of Hesse, and its continued importance since then as an administrative and economic centre, Darmstadt has managed to retain control of key (public) infrastructures and assets, such as its comprehensive tram and public transport network and a well-developed electricity and gas network. ${ }^{27}$ These assets have always been understood as being important to the functioning of the city and the well-being of its citizens, and this is both connected to a particular public ethos as regards the provision of key services, and, importantly, anchored in the administrative approach of 'municipal self-governance' as written into Germany's federal constitution. While there were cases of part-privatisation in the 1990s in Darmstadt's energy sector, 40 per cent of previously privately-held shares were brought back in-house in 2011 and are now in public hands and under the management of the city's public municipal enterprise HEAG Holding AG. The decision to remunicipalise the shares was proposed by the lord mayor of Darmstadt and approved by its city council assembly. Under public management, the energy provider has since become the leading green electricity provider in Germany.

Interestingly, the city was also the first in Germany to develop a Stadtwirtschaftsstrategie, a dedicated 'city economic strategy', concerned with the management of the city's assets and shares. Following a directive of the central German auditing authority, in 2008 the city of Darmstadt assigned to HEAG Holding AG the responsibility of 'asset- and shareholding management'

(Beteiligungsmanagement) - which the city understood as a strategic opportunity to explore which assets it held and where future public investments were needed. The process, repeated every ten years, involved intensive deliberation and discussions with a diversity of political actors across the city, with the resulting city economic strategy being finally approved by the city council assembly in 2009. German public (well-) being provision in general, and Darmstadt's Stadtwirtschaftsstrategie in particular, is inherently linked to continuing strong values of transparency and trust in the public sphere. Reflecting on HEAG Holding AG's role, the management

\footnotetext{
${ }^{26}$ Andrew Cumbers and Sören Becker, 'Making sense of remunicipalisation: theoretical reflections on and political possibilities from Germany's Rekommunalisierung process', Cambridge Journal of Regions, Economy and Society, 1132018.

${ }^{27}$ Interview with a management representative from Darmstadt's municipal enterprise HEAG Holding AG (from our ERC project fieldwork).
} 
representative we interviewed repeatedly emphasised the responsibilities of 'being entrusted with' the effective management of Darmstadt's infrastructures, services and assets for the well-being all of its citizens. ${ }^{28}$ In this vein, the task of providing Daseinsvorsorge is often understood in German contexts to imply a mandate to fulfil the responsibility of well-being provision for citizens. ${ }^{29}$ This mandate of public trust shapes the politics of remunicipalisation in Germany to this day.

\section{Forging broader coalitions of democratic municipalism}

This particular example, within the broader context of the long-standing public ethos in Germany, and the continuing levels of trust and engagement of diverse German publics in municipal management, offers interesting insights into how ordinary everyday municipalisms may be articulated in specific places. Other places will have different socio-cultural histories but will find their own forms of articulation. Struggles by the left at the local level need to be attentive to such older anti-market public values and tendencies. Although the left must also fashion new narratives that build on these values in particular places and contexts: new articulations must not disown these values, or seek to displace them through a more purified set of left narratives that evoke only iconic or 'fearless' radical cities.

In a discussion in 2013, following on from a chapter co-written by one of us for an edited collection in her honour - which ended with a call to address the grievances of those industrial places 'left behind' by neoliberal globalisation - Doreen Massey was remarkable prescient. She highlighted the ability of the right to develop its own local populist narrative (such as those of Houchen in Tees Valley) if the left fails to understand particular localist concerns:

I hope people take seriously your concluding paragraphs. The Motherwell story is really important for the left in the UK to understand right now. That disconnectedness. And of course, the concern about foreign workers. I had a similar conversation in Barrow some months ago ... a man being negative about the local unemployed (my taxes pay for them? - which of course they do). He wasn't 'reactionary' but this local situatedness guided his interpretation (aided by the right wing press).

Bankers and elites seem out of view. The right is so very much better at understanding this train in (much of) the left. (And metropolitan liberals who turn on working class people for being reactionary or racist are even worse) Forgive the rant! But if we can't put ourselves in other people's place (precisely), we're done for. ${ }^{30}$

\footnotetext{
28 Ibid

${ }^{29}$ Ongoing research in the federal State of Thuringia in January 2020 as part of our ERC Project.

${ }^{30}$ Personal email communication with Andrew Cumbers and Paul Routledge, 26 February 2013, in response to Andrew Cumbers and Paul Routledge, 'Place, space and solidarity in global justice network', in D. Featherstone and J. Painter (eds), Spatial Politics: Essays for Doreen Massey, Blackwell 2013.
} 
If a more radical left municipalism is to take hold, it needs to address pre-existing local material concerns and sensibilities while also evoking broader values of social and ecological justice. To be sure, this is a difficult balancing act that needs to be constantly worked at, and, while we are encouraged by new municipalism's desire to return power to 'ordinary people', it is important not to overlook the 'actually existing municipalisms' of those 'ordinary people' themselves. Those continuing struggles ongoing at the local level, both within the local state apparatus and through civil society, workers, trade unions and the broader public, constantly evoke important public and civic values in opposition to (equally ongoing) processes of privatisation and marketisation. Reflecting its origins in anarchist or autonomous Marxist anti-state practice, there is sometimes a sense from the new municipalism rhetoric that the state - and by implication the existing social forces that act through it - needs to be fully reclaimed from neoliberal or corporatist tendencies. This, however, disregards the continuing existence of public values of care, community and reciprocity, which can, and should, be mobilised into coalitions of democratic municipalism. 